$\mathrm{BH}-00639$

Rev. 2

\title{
120-D-1 (100-D) Ponds Training Plan
}

\section{Authors}

G. B. Mitchem

J. P. Zoric

Date Published

June 1996

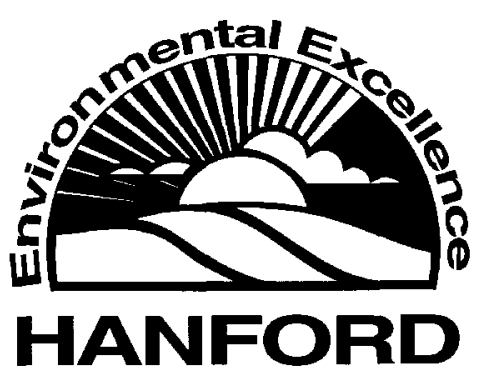

Prepared for the U.S. Department of Energy

Office of Environmental Restoration and

Waste Management

Bechtel Hanford, Inc.

Richland, Washington 
TRADEMARK DISCLAIMER

Reference herein to any specific commercial product, process, or

service by trade name, trademark, manufacturer, or otherwise, does

not necessarily constitute or imply its endorsement,

recommendation, or favoring by the United States Government or any

agency thereof or its contractors or subcontractors.

This report has been reproduced from the best available copy.

Available in paper copy and microfiche.

Available to the U.S. Department of Energy

and its contractors from

Office of Scientific and Technical Information

P.O. Box 62

Oak Ridge, TN 37831

(615) $576-8401$

Available to the public from the U.S. Department of Commerce

National Technical Information Service

5285 Port Royal Road

Springfield, VA 22161

(703) $487-4650$

Printed in the United States of America

DISCLM-5.CHP (8-91) 


\section{CONTENTS}

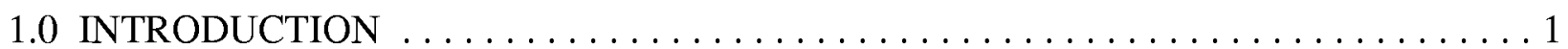

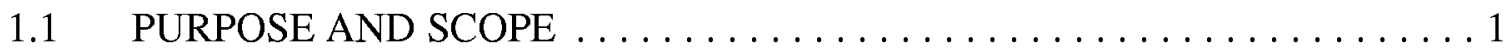

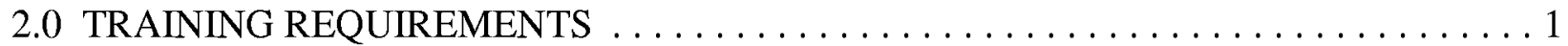

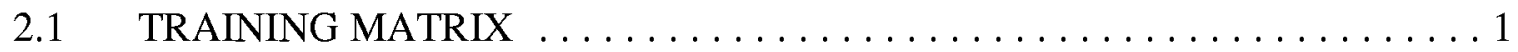

2.1.1 FACILITY PERSONNEL $\ldots \ldots \ldots \ldots \ldots \ldots \ldots \ldots \ldots \ldots \ldots$

2.1 .2 NONFACILITY PERSONNEL $\ldots \ldots \ldots \ldots \ldots \ldots \ldots \ldots \ldots \ldots$

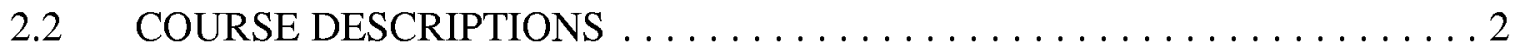

2.2.1 HAZARDOUS WASTE OPERATIONS 24-HOUR OR 40-HOUR AND ANNUAL REFRESHER ................... 2

2.2.2 HANFORD EMPLOYEE SAFETY ORIENTATION (HESO) AND ANNUAL REFRESHER HANFORD GENERAL EMPLOYEE

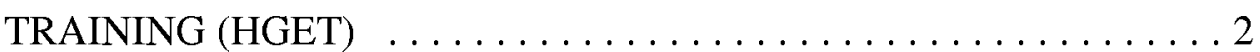

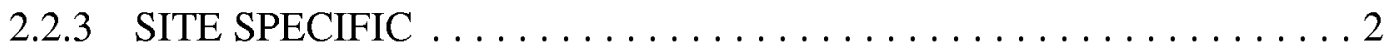

2.2.4 BUILDING WARDEN TRAINING OR BUILDING EMERGENCY DIRECTOR TRAINING AND ANNUAL REFRESHER FOR

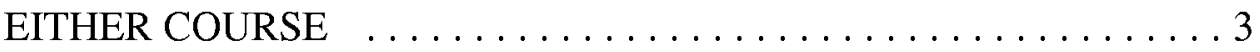

2.3 TRAINING DIRECTOR $\ldots \ldots \ldots \ldots \ldots \ldots \ldots \ldots \ldots \ldots \ldots$

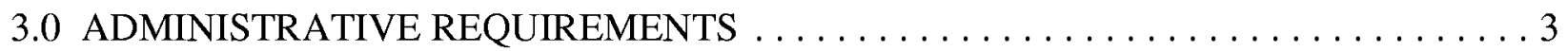

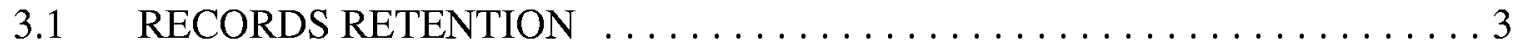

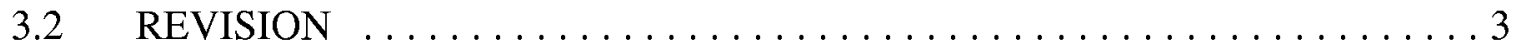

4.0 DANGEROUS WASTE MANAGEMENT POSITION DESCRIPTIONS $\ldots \ldots \ldots \ldots \ldots 4$

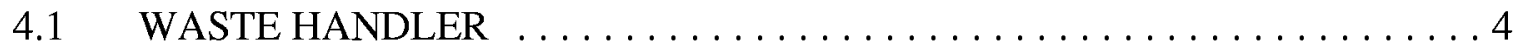

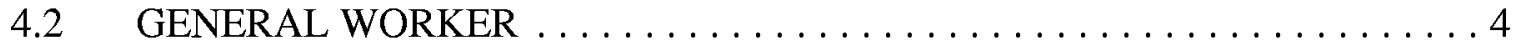

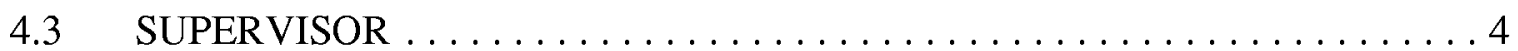

4.4 EMERGENCY COORDINATOR $\ldots \ldots \ldots \ldots \ldots \ldots \ldots \ldots \ldots \ldots$

\section{APPENDICES}

A Employee Listing -Waste Handlers $\ldots \ldots \ldots \ldots \ldots \ldots \ldots \ldots \ldots \ldots \ldots \ldots \ldots$

B Site-Specific Training Plan $\ldots \ldots \ldots \ldots \ldots \ldots \ldots \ldots \ldots \ldots \ldots \ldots \ldots \ldots \ldots$

\section{TABLE}

$2-1$. Training Requirements for $100-D$ Ponds Treatment, Storage, and Disposal Unit Workers 


\subsection{INTRODUCTION}

\subsection{PURPOSE AND SCOPE}

This is the Environmental Restoration Contractor (ERC) Team training plan for the $100-\mathrm{D}$ Ponds treatment, storage, and disposal (TSD) unit. This plan is intended to meet the requirements of WAC 173-303-330 and the Hanford Dangerous Waste Permit. Training unrelated to compliance with WAC 173-303-330 is not addressed in this training plan. The WAC 173-303-330(1)(d)(ii, v, vi) requires that personnel be familiar, where applicable, with waste feed cut-off systems, proper responses to groundwater contamination incidents, shutdown of operations, response to fire or explosion, and other process operation activities. The 100-D Ponds TSD unit is no longer receiving or storing dangerous waste; therefore, the requirements in WAC 173-303-330(1)(d)(ii, $\mathrm{v}, \mathrm{vi}$ ) are not relevant to this unit and are not covered in this training plan.

\subsection{TRAINING REQUIREMENTS}

\subsection{TRAINING MATRIX}

\subsubsection{FACILITY PERSONNEL}

Table $2-1$ provides a matrix of the training facility personnel must receive relative to their position each calendar year to perform work at the 100-D Ponds TSD Unit. After a course has been taken, only a refresher course is necessary for subsequent years. Training must be successfully completed by personnel within 6 months after employment at or assignment to 100D Ponds TSD Unit or associated inspection functions. Within the 6-month period, employees must be supervised until they complete training required for their position.

\subsubsection{NONFACILITY PERSONNEL}

If nonfacility personnel (such as delivery truck drivers or Washington State Department of Ecology inspectors) will be anywhere near dangerous waste management activities, they must receive site-specific training relative to $100-\mathrm{D}$ Ponds or be escorted by trained personnel. 
BHI-00639

Rev. 2

Table 2-1. Training Requirements for 100-D Ponds Treatment, Storage, and Disposal Unit Workers.

\begin{tabular}{|l|c|c|c|c|}
\hline Category & Waste Handlers & $\begin{array}{c}\text { General } \\
\text { Workers }\end{array}$ & Supervisors & $\begin{array}{c}\text { Emergency } \\
\text { Coordinators }\end{array}$ \\
\hline $\begin{array}{l}\text { Hazardous } \\
\text { Opaste }\end{array}$ & Yes & No & Yes & Yes \\
\hline HESO/HGET & Yes & Yes & Yes & Yes \\
\hline $\begin{array}{l}100-D \text { Ponds } \\
\text { Site Specific }\end{array}$ & Yes & Yes & Yes & Yes \\
\hline $\begin{array}{l}\text { Building } \\
\text { Warden/BED }\end{array}$ & No & No & No & Yes \\
\hline
\end{tabular}

HESO = Hanford Employee Safety Orientation

HGET $=$ Hanford General Employee Training.

\subsection{COURSE DESCRIPTIONS}

\subsubsection{HAZARDOUS WASTE OPERATIONS 24-HOUR OR 40-HOUR AND ANNUAL REFRESHER}

This course provides training relative to dangerous waste management, hazard identification, and protective clothing.

\subsubsection{HANFORD EMPLOYEE SAFETY ORIENTATION (HESO) AND ANNUAL REFRESHER IANFORD GENERAL EMPLOYEE TRAINING (HGET)}

This course provides training relative to contingency plan implementation, effective response to emergencies, communications and alarm systems, and response to fire or explosion.

\subsubsection{SITE SPECIFIC}

This course provides unit-specific training relative to dangerous waste management hazards, contingency plan implementation, effective response to emergencies, and communications and alarm systems. 


\subsubsection{BUILDING WARDEN TRAINING OR BUILDING EMERGENCY DIRECTOR TRAINING AND ANNUAL REFRESHER FOR EITHER COURSE}

This course provides training relative to emergency coordinator responsibilities.

\subsection{TRAINING DIRECTOR}

Personnel directing training under this plan shall be knowledgeable in dangerous waste management procedures.

\subsection{ADMINISTRATIVE REQUIREMENTS}

\subsection{RECORDS RETENTION}

This training plan includes employee training records. The employee training records are maintained electronically. This training plan shall be kept at the Hanford Site and be readily retrievable. A hard copy of any site-specific training that is not recorded electronically must be kept on file and be readily retrievable.

\subsection{REVISION}

The task manager is responsible for keeping this training plan up to date. This training plan shall be revised whenever the following occur:

C When titles or numbers of training courses change

C When employees change positions

C When new employees are assigned to the 100-D Ponds TSD Unit

C When training requirements in WAC 173-303-330 or the Hanford Site dangerous waste permit are revised. 


\subsection{DANGEROUS WASTE MANAGEMENT POSITION DESCRIPTIONS}

This training plan applies only to employees who perform work at the $100-D$ Ponds or are Emergency Coordinators. If an employee fits into more than one position, he or she will receive the highest level of training applicable to the positions.

\subsection{WASTE HANDLER}

Duties include the following:

C Perform inspections

C Treat wastes

C Perform treatability tests

C Take samples

C Package and ship waste

C Respond to emergencies.

Required skills are basic communication skills, and the ability to follow instructions. There are no specific education or other qualification requirements.

\subsection{GENERAL WORKER}

Duties include the following:

C Perform inspections

C Respond to emergencies

C Provide maintenance services

C Operate equipment

C Set up equipment.

Required skills are basic communication skills, and the ability to follow instructions. There are no specific education or other qualification requirements.

\subsection{SUPERVISOR}

Duties include the following:

C Supervise waste handlers and general workers

$\mathrm{C} \quad$ Assure personnel training 
C Perform inspections

C Respond to emergencies.

Required education includes a 4-year college degree or equivalent knowledge and experience. There are no other required qualifications.

\subsection{EMERGENCY COORDINATOR}

Duties include proper response to emergencies per WAC 173-303-360. Required education includes a 4 -year college degree or equivalent knowledge and experience. There are no other required qualifications. 


\section{APPENDIX A}

EMPLOYEE LISTING -WASTE HANDLERS 


\section{A1.0 WASTE HANDLER}

Employees listed in this table are Waste Handlers that are qualified to work at the $100-D$ Ponds TSD Unit. Refer to the training matrix (Table 2-1 in Section 2.1) to determine training requirements for Waste Handlers.

\begin{tabular}{|l|l|}
\hline B. Brown & 8 A000 \\
\hline D. Haugen & 84375 \\
\hline F. Hubbard & $8 \mathrm{~A} 172$ \\
\hline L. Martell & 85902 \\
\hline I. Mata & 82697 \\
\hline G. Potter & 82745 \\
\hline
\end{tabular}

\section{A2.0 GENERAL WORKER}

Employees listed in this table are General Workers that are qualified to work at the $100-D$ Ponds TSD Unit. Refer to the training matrix (Table $2-1$ in Section 2.1) to determine training requirements for General Workers.

\begin{tabular}{|l|l|}
\hline B. Brown & $8 \mathrm{~A} 000$ \\
\hline D. Haugen & 84375 \\
\hline F. Hubbard & $8 \mathrm{~A} 172$ \\
\hline L. Martell & 85902 \\
\hline I. Mata & 82697 \\
\hline G. Potter & 82745 \\
\hline
\end{tabular}




\section{A3.0 SUPERVISOR}

Employees listed in this table are Supervisors that are qualified to work at the 100-D Ponds TSD Unit. Refer to the training matrix (Table $2-1$ in Section 2.1) to determine training requirements for Supervisors.

\begin{tabular}{|l|l|}
\hline W. Osborne & 64212 \\
\hline
\end{tabular}

\section{A4.0 EMERGENCY COORDINATOR}

Employees listed in this table are Emergency Coordinators that are qualified to work at the 100D Ponds TSD Unit. Refer to the training matrix (Table $2-1$ in Section 2.1) to determine training requirements for Emergency Coordinators.

\begin{tabular}{|l|l|}
\hline W. Hayward & 66516 \\
\hline W. Osborne & 64212 \\
\hline
\end{tabular}




\section{APPENDIX B}

SITE-SPECIFIC TRAINING PLAN 


\section{B1.0 OBJECTIVES}

Site-specific training will provide the facility worker with the facility-specific knowledge relative to the following:

C Dangerous waste management hazards

C Contingency plan implementation

$\mathrm{C} \quad$ Effective response to emergencies

C Communications and alarm systems.

\section{B1.1 DESCRIPTION}

The 100-D Ponds TSD unit is located adjacent to and north of the north perimeter fence of the $100-D$ Area. The unit was constructed primarily for the impoundment, treatment, and disposal of nonradioactive, nondangerous liquid effluent from the 183-D Water Treatment Facility (WTF) and began operations in 1977. This unit currently consists of two surface ponds interconnected by effluent transfer piping.

Beginning in 1950, before the operation of this site as a TSD unit, this location served as the $188-D$ Ash Disposal Basin which received coal ash from the $184-D$ Powerhouse. Between 1950 and 1966, the location only received ash/water effluent. The ash basin was retired in 1966, and between 1966 and 1977 the site received no discharges. By 1977, when pond operations began, the $100-\mathrm{D}$ Area industrial sewer system had been permanently diverted to discharge solely into $100-\mathrm{D}$ Ponds. All discharges to this location have arrived by the same influent pipe from the $100-\mathrm{D}$ Area process sewer system. The pond was operated as a TSD facility until June 1994 when all discharges to the pond ceased.

The sources of effluent that entered the 100-D Ponds are the $183-\mathrm{D}$ WTF, the $182-\mathrm{D}$ Reservoir, and the 189-D Mechanical Development Laboratory (MDL). The average 183-D WTF daily discharge to the pond was 19 to $265 \mathrm{~L} / \mathrm{min}$ ( 5 to $70 \mathrm{gal} / \mathrm{min}$ ). In addition to this daily discharge, the $183-\mathrm{D}$ WTF multimedia filters were backwashed monthly. This generated $530,600 \mathrm{~L}$ $(140,100 \mathrm{gal})$ of waste discharged to $100-\mathrm{D}$ Ponds. Biannually, the $183-\mathrm{D}$ WTF settling ponds were washed down and this generated 2,728,800 L (720,400 gal) of waste per year that was discharged to the pond. Any discharge from the $182-\mathrm{D}$ Reservoir resulted from reservoir overflow and consisted of raw water from the Columbia River. From 1977 to 1988, discharge from the 189-D MDL contributed to the waste disposed at 100-D Ponds. The 189-D MDL complex consisted of activities involved in the 185-D/189-D, 190-D, 190-DA, and 1724-DA facilities. The discharges from these facilities were small and of an intermittent nature. The $100-D$ Ponds is identified as a TSD unit because the 189-D MDL complex discharged corrosive demineralizer regenerative solutions to the pond. Corrosive wastes are classified as characteristic dangerous waste, waste code $\mathrm{D} 002$. The $100-\mathrm{D}$ Ponds have not received dangerous waste since January 1986. 


\section{B1.2 DANGEROUS WASTE MANAGEMENT HAZARDS}

The facility no longer receives waste water. Because no waste water is being discharged, no immediate dangerous waste hazards are present. The facility is secured by a single strand cable with warning signs posted on the cable. The two sampling programs performed to date have indicated a radioactive "crust" over most of the settling pond bottom of approximately $100 \mathrm{mrem} / \mathrm{yr}$ and the soil beneath it at slightly elevated levels of approximately $30 \mathrm{mrem} / \mathrm{yr}$. There are also elevated levels of polychlorinated byphenyls within the soil in the northeast corner of the pond at levels up to 30 parts per million (ppm) and metals contamination of arsenic and lead just above the regulatory release limits (maximum values in soil of $62.2 \mathrm{ppm}$ and $519 \mathrm{ppm}$ for arsenic and lead, respectively).

Cleanup of contaminated materials, including removal of piping and contaminated soil associated with past waste disposal practices, is planned. Approximately $1,030 \mathrm{~m}^{3}\left(1,350 \mathrm{yd}^{3}\right)$ of sediment removal will be excavated for disposal. Pipes embedded in the earthen dike between the two ponds and corrugated pipe located in the percolation pond will be removed. Waste materials will be transported to the appropriate disposal facility, and noncontaminated material will be stored adjacent to the D-Ponds.

\section{B1.3 IMPLEMENTATION OF THE SITE-SPECIFIC CONTINGENCY PLAN}

The site-specific contingency plan can be obtained through the Facility Emergency Coordinator, document control center, or the inspection supervisor. Each worker must be familiar with the site-specific contingency plan and its requirements. The site-specific contingency plan will be implemented by the Facility Emergency Coordinator whenever there is an immediate threat to human health or the environment.

\section{B1.4 RESPONSE TO EMERGENCIES}

All emergencies (e.g., fires, explosions, personnel injury) shall be reported to the Facility Emergency Coordinator who will respond to all emergencies as outlined in the Facility Specific Contingency Plan and the Hanford Site Contingency Plan.

\section{B1.5 COMMUNICATIONS}

There are no fixed communication systems at 100-D Ponds. Work at 100-D Ponds will always involve at least two people with portable communication devices (e.g., cellular phones, radios, etc.). 


\section{B1.6 ALARMS}

Normal Hanford Sitewide audible emergency signals will be observed. No facility specific alarms are necessary for $100-D$ Ponds.

\section{B1.7 MONITORING}

Required monitoring is outlined in the Facility Specific Inspection Plan and is performed by the Hanford Site Groundwater Monitoring Program.

\section{B1.8 INSPECTIONS}

It is required that the $100-\mathrm{D}$ Ponds be inspected at least once each calendar quarter of the year, in accordance with the Facility Specific Inspection Plan.

\section{B1.9 ENVIRONMENTAL HAZARDS}

The $100-\mathrm{D}$ Ponds are approximately 3.7 to $5.5 \mathrm{~m}$ (12 to $18 \mathrm{ft}$ ) deep with some relatively steep but stable side slopes. Accumulation of water at the bottom of the ponds from storm events is possible but has not been visibly identified in the past as being a significant concern. Environmental hazards consist of snakes, spiders, varmints, tripping hazards, extreme heat in the summer, and extreme cold in the winter.

\section{B1.10 RADIOLOGICAL HAZARDS}

The $100-\mathrm{D}$ Ponds is a radiological controlled area; a Radiation Work Permit is required to enter the facility.

\section{B1.11 DOCUMENTS TO BE REVIEWED}

Each facility worker must review and be cognizant of the following site-specific documents:

C 100-D Ponds Site Specific Contingency Plan

C $\quad 100-D$ Ponds Site Specific Inspection Plan

C 100-D Ponds Site Specific Waste Analysis Plan

C $\quad 100-D$ Ponds Site Specific Training Plan. 